\title{
The Ribosomal Intergenic Spacer and Domain I of the 23S rRNA Gene Are Phylogenetic Markers for Chlamydia spp.
}

\author{
KARIN D. E. EVERETT* AND ARTHUR A. ANDERSEN \\ Avian and Swine Respiratory Diseases Research Unit, National Animal Disease Center, \\ Agricultural Research Service, U.S. Department of Agriculture, Ames, Iowa 50010
}

\begin{abstract}
Current methods used to classify Chlamydia strains, including biological, morphological, and DNA hybridization techniques and major outer membrane protein (omp1) gene analysis, can be imprecise or difficult to perform. To facilitate classification, 2.8-kb partial ribosomal DNA (rDNA) segments from a Chlamydia trachomatis strain and a Chlamydia psittaci strain were amplified by PCR and sequenced. Subsequently, a 1,320-bp region in this segment, including both the $16 \mathrm{~S} / 23 \mathrm{~S}$ intergenic spacer $(232 \pm 11 \mathrm{bp})$ and domain $\mathrm{I}(620 \pm 2 \mathrm{bp})$ of the 23S gene, was sequenced from 41 additional strains and from the chlamydia-like organisms Simkania sp. strains " $Z$ " and "Z1." When both parsimony and distance analyses were performed, these sequences were found to have variable regions that grouped the isolates into two lineages $(C$. trachomatis and non- $C$. trachomatis) and nine distinct genotypic groups. The $C$. trachomatis lineage included human, swine, and mousehamster groups. The non-C. trachomatis lineage included Chlamydia pecorum, Chlamydia pneumoniae, and $C$. psittaci abortion, avian, feline, and guinea pig groups. These nine groups were essentially equidistant from the genetic root and were congruent with groups identified previously by using DNA-DNA homology, genomic restriction endonuclease analysis, host specificity, tissue specificity, and/or disease production. Phylogenetic trees based on the intergenic spacer or on domain I were congruent with trees previously derived from ompI sequences. DNA sequence analysis of either the intergenic spacer or domain I provides a rapid and reproducible method for identifying, grouping, and classifying chlamydial strains.
\end{abstract}

Chlamydia spp. are obligately intracellular bacteria that replicate only in cytoplasmic inclusions of eukaryotic cells. Some 60 phenotypically distinguishable strains infect mammals and birds. Chlamydia trachomatis is taxonomically differentiated from Chlamydia psittaci by its capacity to synthesize glycogen and its sensitivity to sulfadiazine $(50,56)$. Although inconsistencies have been known to exist within this taxonomic system, initially it was thought to separate human strains from most animal strains. $C$. psittaci, containing predominantly animal strains, is a particularly heterogeneous taxon. Recently, some $C$. psittaci strains have been reclassified as members of the separate species Chlamydia pneumoniae (35) and Chlamydia pecorum (26). Current methods for identifying chlamydiae include DNA endonuclease restriction, PCR analysis, restriction fragment length polymorphism (RFLP) analysis, analysis of the sequence of the gene for the major outer membrane protein (ompl), identification of plasmids, histochemical staining, antigenicity analysis, serological techniques, infectivity analysis, and isolation $(3,11,15,18,27,38,44,80)$.

In 1995, Kahane et al. showed that a chlamydia-like organism, provisionally designated Simkania sp. strain "Z," is the closest known relative of the genus Chlamydia (43). The genus Simkania is morphologically a member of the order Chlamydiales. Analysis of $16 \mathrm{~S}$ gene sequences, a method which is widely used to classify genera and higher taxa $(76,85,96)$, clearly shows that the genera Simkania and Chlamydia are separate taxa in this order $(1 \mathrm{a}, 30,43,62,62 \mathrm{a}, 90,92,99)$. The usefulness of $16 \mathrm{~S}$ genes in diagnosis and differentiation of Chlamydia species and strains is limited, however, as these genes are 93 to $97 \%$ identical.

In this study, the $16 \mathrm{~S} / 23 \mathrm{~S}$ intergenic spacer and flanking ribosomal segments were subjected to a DNA sequence anal-

* Corresponding author. Mailing address: National Animal Disease Center, P.O. Box 70, Ames, IA 50010. Phone: (515) 239-8414. Fax: (515) 239-8458. E-mail: keverett@nadc.ars.usda.gov. ysis to determine if they could be used to systematically identify and differentiate chlamydiae. This region was examined because several studies have revealed that there is some sequence diversity near the chlamydial $16 \mathrm{~S}$ gene $(19,27,72)$. A total of 43 Chlamydia isolates and the Simkania sp. strains " $Z$ " and "Z1" were studied. Comparative analyses yielded phylogenetic trees that distinguished both previously established and new groups of chlamydiae.

\section{MATERIALS AND METHODS}

Bacterial strains and culture conditions. A total of 43 Chlamydia strain obtained from both animal and human hosts were used in this study (Table 1). Many of these organisms have been cultured in our laboratory by using Vero or McCoy cell cultures or developing chicken embryos (3) (Table 1). DNA samples from other isolates were provided by workers in laboratories which have been involved in characterization of these organisms (Table 1). All organisms were previously characterized by microimmunofluorescence, serology, ompl sequence analysis, RFLP analysis, DNA hybridization, and/or in vitro growth.

DNA preparation, amplification, and cloning. Genomic DNAs from intact chlamydiae were prepared by incubating the chlamydiae at $37^{\circ} \mathrm{C}$ in 50 to $100 \mu$ of $50 \mathrm{mM}$ dithiothreitol-30 mM Tris-10 mM EDTA ( $\mathrm{pH} 9.0$ ) for $1 \mathrm{~h}$, adding an equal volume of $1 \%$ Nonidet P-40, incubating the preparation for $1 \mathrm{~h}$, adding RNase, incubating the preparation at $37^{\circ} \mathrm{C}$ for $1 \mathrm{~h}$, extracting the preparation with phenol-chloroform (68), and finally extracting the preparation with chloroform. Chlamydial material that was shipped to us as DNA or as lysates was treated with RNase prior to PCR amplification. Approximately $0.25 \mu \mathrm{g}$ of template DNA was used in each $50-\mu l$ PCR mixture; higher concentrations of template DNA were used for specimens of DNA that had not been freshly prepared. The PCR Reagent Kit (Perkin-Elmer, Foster City, Calif.) was used to amplify a single-band 2.8 -kb PCR product from each strain in an OmniGene Temperature Cycler (Hybaid, Middlesex, England) with the following parame ters: 30 cycles consisting of $25 \mathrm{~s}$ at $95^{\circ} \mathrm{C}, 15 \mathrm{~s}$ at $55^{\circ} \mathrm{C}$, and $100 \mathrm{~s}$ at $72^{\circ} \mathrm{C}$ and a final 7 -min extension at $72^{\circ} \mathrm{C}$. The $16 \mathrm{~S}$ oligonucleotide primer used in this amplification reaction mixture, \#U16SF, matched three known $16 \mathrm{~S}$ chlamydial sequences, the sequences of $C$. psittaci $6 \mathrm{BC}^{\mathrm{T}}(\mathrm{T}=$ type strain) (GenBank accession number M13769), C. trachomatis L2/434/BU (GenBank accession number M59178), and C. pneumoniae TW-183 ${ }^{\mathrm{T}}$ (GenBank accession number L06108), at approximately position 990 of the 1,540-bp gene. The $23 \mathrm{~S}$ oligonucleotide primer used in this amplification mixture, \#U23SR, complemented a highly conserved sequence at bacterial 23S gene position 2000 , far enough into the 2,900-bp gene to obtain PCR products representing bona fide rRNA operons and to include a chlamydiaspecific sequence, as well as possible intra-23S spacers. The primer sequences 
TABLE 1. Strains, references, and sources

\begin{tabular}{|c|c|c|}
\hline Strain & Reference(s) & Source $^{a}$ \\
\hline \multicolumn{3}{|l|}{ C. psittaci strains } \\
\hline CP3 (= VR 574) & 57 & NADC \\
\hline MN (= VR 122) & 23 & NADC \\
\hline MN Zhang & 23,98 & Caldwell \\
\hline $6 \mathrm{BC}^{\mathrm{T}}\left(=\operatorname{VR} 125^{\mathrm{T}}\right)$ & 34 & NADC \\
\hline${\mathrm{M} 56^{b}}^{b}$ & 73 & NADC \\
\hline NJ1 & 54 & NADC \\
\hline $\mathrm{CT}^{c}{ }^{c}$ & 53 & NADC \\
\hline GD & 41 & NADC \\
\hline Par1 & 79 & Storey \\
\hline WC & 55 & $\mathrm{NADC}$ \\
\hline EBA & 60 & NADC \\
\hline A22 & 47,77 & Herring \\
\hline B577 (= VR 656) & 81 & NADC \\
\hline OSP & 7 & NADC \\
\hline $\mathrm{FP}(=\mathrm{VR} 120)$ & 9 & $\mathrm{NADC}$ \\
\hline FP Cello & 16 & NVSL \\
\hline FP Vaccine & & Solvay \\
\hline GPIC (= VR 813) & 51 & NADC \\
\hline \multicolumn{3}{|l|}{ C. pecorum strains } \\
\hline $1710 \mathrm{~S}$ & 44,45 & Kaltenboeck \\
\hline BP-1 & 24 & NADC \\
\hline $\mathrm{E} 58^{\mathrm{T}}\left(=\mathrm{VR} 628^{\mathrm{T}}\right)$ & 49 & NADC \\
\hline IPA & 58 & $\mathrm{NADC}$ \\
\hline L71 & 44,45 & Herring \\
\hline $\mathrm{Z}$ & 93 & NADC \\
\hline \multicolumn{3}{|l|}{ C. pneumoniae strains } \\
\hline CM-1 & 12 & Black \\
\hline CWL-029 & 12 & Black \\
\hline CWL-1011 & 12 & Black \\
\hline FML-12 & 12 & Black \\
\hline FML-16 & 12 & Black \\
\hline N16 & 94 & Storey \\
\hline$T W-183^{T}$ & 46 & Campbell \\
\hline \multicolumn{3}{|l|}{ C. trachomatis strains } \\
\hline A/Har-13 & 87 & Caldwell \\
\hline $\mathrm{B} / \mathrm{TW}-5 / \mathrm{OT}$ & 87 & Caldwell \\
\hline $\mathrm{D} / \mathrm{UW}-3 / \mathrm{CX}$ & 88 & Caldwell \\
\hline F/IC/CAL3 & 37 & Caldwell \\
\hline $\mathrm{L} 2 / 434 / \mathrm{BU}$ & 70 & Caldwell \\
\hline R22 & 5 & NADC \\
\hline $\mathrm{R} 24$ & 5 & $\mathrm{NADC}$ \\
\hline R27 & 5 & $\mathrm{NADC}$ \\
\hline H5 & 4 & NADC \\
\hline S45 & 44 & Kaltenboeck \\
\hline MoPn (= VR 123) & 52 & Caldwell \\
\hline SFPD & 78 & Fox \\
\hline \multicolumn{3}{|l|}{ Chlamydia-like organisms } \\
\hline Simkania sp. strain " $Z$ " & 43 & Kahane \\
\hline Simkania sp. strain " $\mathrm{Z} 1$ " & & Kahane \\
\hline
\end{tabular}

${ }^{a}$ NADC, Avian and Swine Respiratory Diseases Research Unit, Nationa Animal Disease Center, Agricultural Research Service, U.S. Department of Agriculture, Ames, Iowa; Caldwell, H. D. Caldwell; Storey, C. Storey; Herring, A. J. Herring; NVSL, Diagnostic Virology Laboratory, National Veterinary Services Laboratories, Animal and Plant Health Inspection Service, U. S. Department of Agriculture, Ames, Iowa; Solvay, Solvay Animal Health, Inc., Mendota Heights, Minn.; Kaltenboeck, B. Kaltenboeck; Black, C. M. Black; Campbell, L. A. Campbell; Fox, J. G. Fox; Kahane, S. Kahane.

${ }^{b}$ Strain M56 was a yolk sac passage strain of the original preparation and was not VR 630, the isolate available from the American Type Culture Collection. VR 630 is a mixed culture which in Vero cells grows out as strain M56 and in McCoy host cells grows out as strain FP (4).

${ }^{c} \mathrm{CT} 1$ was called $\mathrm{C} 1$ by Page (53).

were as follows: \#U16SF, GCATGTGGTTTAATTCGATGCAACGCGAAGA ACC; and \#U23SR, GAATTTCGCTACCTTAGGACCGTTATAGTTAC Clones of the 2.8-kb ribosomal PCR products were prepared for DNA sequencing by using a TA Cloning Kit (Invitrogen, San Diego, Calif.).

DNA sequence analysis. Oligonucleotide primer synthesis and DNA sequencing were performed by workers at the Iowa State University DNA Sequencing and Synthesis Facility, Ames. The full-length, cloned, 2.8-kb PCR products from strains R22 and $\mathrm{NJ} 1$ were subjected to a double-stranded DNA sequence analysis. After comparison of these sequences, the homologous 2.8 -kb PCR products were prepared from 41 additional strains (Table 1) and from Simkania sp. strain "Z" (43) and "Z1" (provided by S. Kahane as "ZV1" because it was a possible contaminant of " $Z$ "). Clones and PCR products were characterized by cutting them with restriction enzyme EcoRI. EcoRI cut all 2.8-kb chlamydial PCR products at a single site, yielding 1.7- and 1.1-kb fragments. A number of the 2.8 -kb cloned PCR products obtained during clone screening could not be cu with EcoRI, and a DNA sequence analysis of more than 500 bases of each product, performed by using a universal primer for the cloning vector, identified the products as a Mycoplasma orale ribosomal sequence. In addition, unlike the chlamydial products, the PCR products obtained from Simkania sp. strains " $Z$ " and " $\mathrm{Z1}$ " were not cut by EcoRI.

A 1,320 -bp segment in each of the 412.8 -kb products was subjected to doublestranded DNA sequence analysis. A total of 33 of the sequences were obtained from clones of the PCR product in vector pCRII (Invitrogen); other sequences were determined by directly sequencing 2.8 -kb PCR products that had been extracted with phenol-chloroform and chloroform (68) and concentrated with Microcon 100 microconcentrators (Amicon Corp., Beverly, Mass.). The entire sequences of strains R27, CT1, and GPIC were determined from both PCR products and clones. Because $C$. trachomatis has been reported to have two ribosomal operons $(19,27)$, the sequences of the highly variable segments of $C$ trachomatis A/Har-13 ${ }^{\mathrm{T}}, \mathrm{B} / \mathrm{TW}-5 / \mathrm{OT}, \mathrm{D} / \mathrm{UW}-3 / \mathrm{CX}, \mathrm{F} / \mathrm{IC} / \mathrm{CAL} 3, \mathrm{~L} 2 / 434 / \mathrm{BU}$, and R22 were determined from both clones and PCR products to look for ambiguous sequence data. The sequences of 10 chlamydial strains (1710S, EBA, FP Cello, IPA, N16, M56, L71, Par1, S45, and TW-183 ) and of Simkania sp. strains " $Z$ " and "Z1" were obtained from the PCR product template alone.

Several primers were found to be particularly useful for PCR amplification and sequencing, because they matched or complemented all of the chlamydial sequences. The locations of these primers are shown in Fig. 1. The forward primers used were primers \#16SF2 (CCGCCCGTCACATCATGG) and \#16SF3 (TCG TAACAAGGTAGCCC). The complementary primers used were primers \#23R (TACTAAGATGTTTCAGTTC), \#23R2 (AAAAGGCACGCCGTCAACC), \#23R3 (GATATCTCCAAGTTTGATT), and \#23R4 (GAGCTGTTACGCAC TCTTT). Primer \#16SF2 is located 150 bases before the $3^{\prime}$ end of the $16 \mathrm{~S}$ gene, primer \#23R is located about 200 bases after the start of the 23S gene, primer \#23R2 is located at the $3^{\prime}$ end of domain I, primer \#23R3 is located about 12 bases beyond the end of the 1,320-bp sequenced segment, and \#23R4 is located about 1,200 bp into the $23 \mathrm{~S}$ gene. Double-stranded DNA sequence data were compiled from approximately 70,000 bp of PCR products and/or clones. To gauge the accuracy of sequence analysis, more than $10,000 \mathrm{bp}$ was examined by using both cloned and direct PCR templates.

Primer extension analysis. Total RNAs were prepared from lysed $C$. psittaci $6 \mathrm{BC}^{\mathrm{T}}, C$. psittaci $\mathrm{NJ} 1$, and $C$. trachomatis $\mathrm{R} 22$ by repeated phenol-chloroform extraction and DNase treatment and were used as templates in a primer extension analysis. Primer extension to identify the $5^{\prime}$ end of the $23 \mathrm{~S}$ rRNA was carried out by using a conserved primer complementing the chlamydial $23 \mathrm{~S}$ rRNA (primer \#23R [TACTAAGATGTTTCAGTTC]) and the GeneAmp Thermostable $\mathrm{r}$ Tth Reverse Transcriptase RNA PCR kit (Perkin-Elmer). $\left[{ }^{32} \mathrm{P}\right] \mathrm{dCTP}$ was incorporated into the $r$ Tth Reverse Transcriptase product with the following changes in the manufacturer's recommended conditions: the reverse transcription mixture was prepared by using unlabeled dCTP at one-half the recommended concentration, $\mathrm{MnCl}_{2}$ and $\mathrm{r} T$ th enzyme were omitted, and the mixture was heated for $5 \mathrm{~min}$ in a boiling water bath. The heated mixture was cooled rapidly on ice, and $40 \mu \mathrm{Ci}$ of $\left[{ }^{32} \mathrm{P}\right] \mathrm{dCTP}$ (ICN, Irvine, Calif.), $\mathrm{MnCl}_{2}$, and $\mathrm{rTth}$ enzyme were added. Extension was carried out for one cycle in a model 9600 GeneAmp PCR System (Perkin-Elmer) by using the following conditions: $10 \mathrm{~min}$ at $50^{\circ} \mathrm{C}, 15 \mathrm{~min}$ at $70^{\circ} \mathrm{C}$, and $1 \mathrm{~min}$ at $95^{\circ} \mathrm{C}$. For each chlamydial strain, one sequence ladder was prepared with $\left[{ }^{32} \mathrm{P}\right] \mathrm{dCTP}$ label and another sequence lad der was prepared with ${ }^{35}$ S-labeled dATP (ICN) by using the CircumVent Thermal Cycle Dideoxy DNA Sequencing Kit (New England Biolabs, Beverly, Mass.)

DNA analysis programs and output. Sequence analysis programs described in the Program Manual for the Wisconsin Package (30a), Madison, were used for DNA and RNA analyses. These programs were the Reformat, SeqEd, BestFit, Gap, Reverse, Assemble, PileUp, Pretty, LineUp, Distances, FastA, RNAfold, and Squiggles programs. Phylogenetic distances were determined by Robin $\mathrm{M}$. Bush and Walter Fitch, who performed a parsimony analysis with PAUP version 3.1 (83). The branching order reliability was evaluated by examining 100 bootstrap resampling replications (21). Sequence data were examined in the following four ways: (i) a PileUp multiple-sequence alignment, including appropriate gaps and substitutions, was prepared (Fig. 2 is a Pretty display of a PileUp alignment) (ii) by using the PileUp alignment, distance analysis tables containing JukesCantor pairwise corrected difference values (42) were generated for the intergenic spacer and for domain I (Tables 2 through 4 summarize these data); (iii) outgroup sequence data were obtained from GenBank for Pirellula marina (accession number X07408) and by sequencing the DNAs of Simkania sp. strains "Z" and "Z1"; and (iv) the sequences were analyzed by using PAUP, the most parsimonious consensus trees were prepared, and branching order reliability was tested by examining 100 bootstrap sampling replications. Finally, biological, serological, and host range data were compiled and a rooted domain I tree was prepared. 


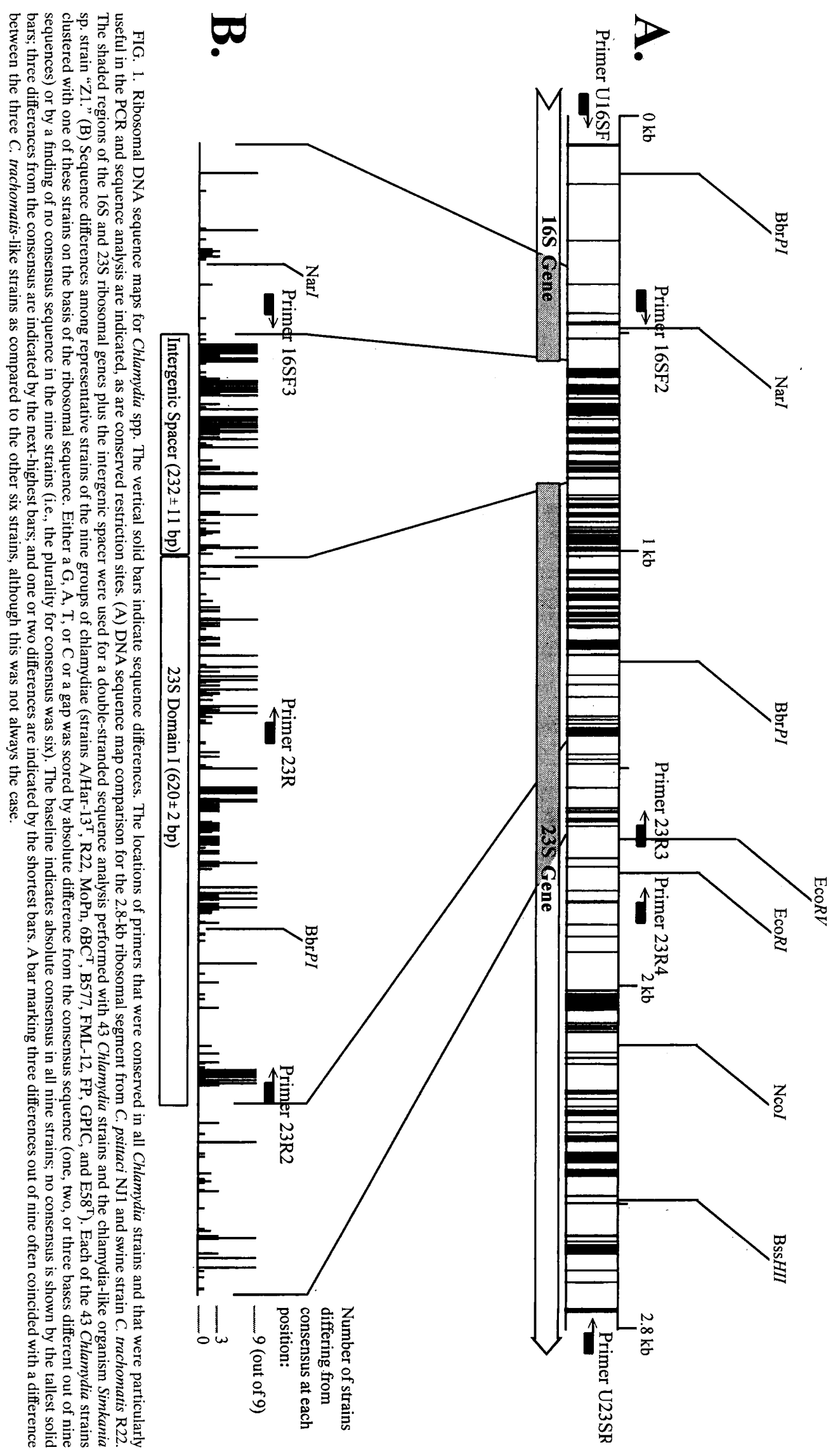



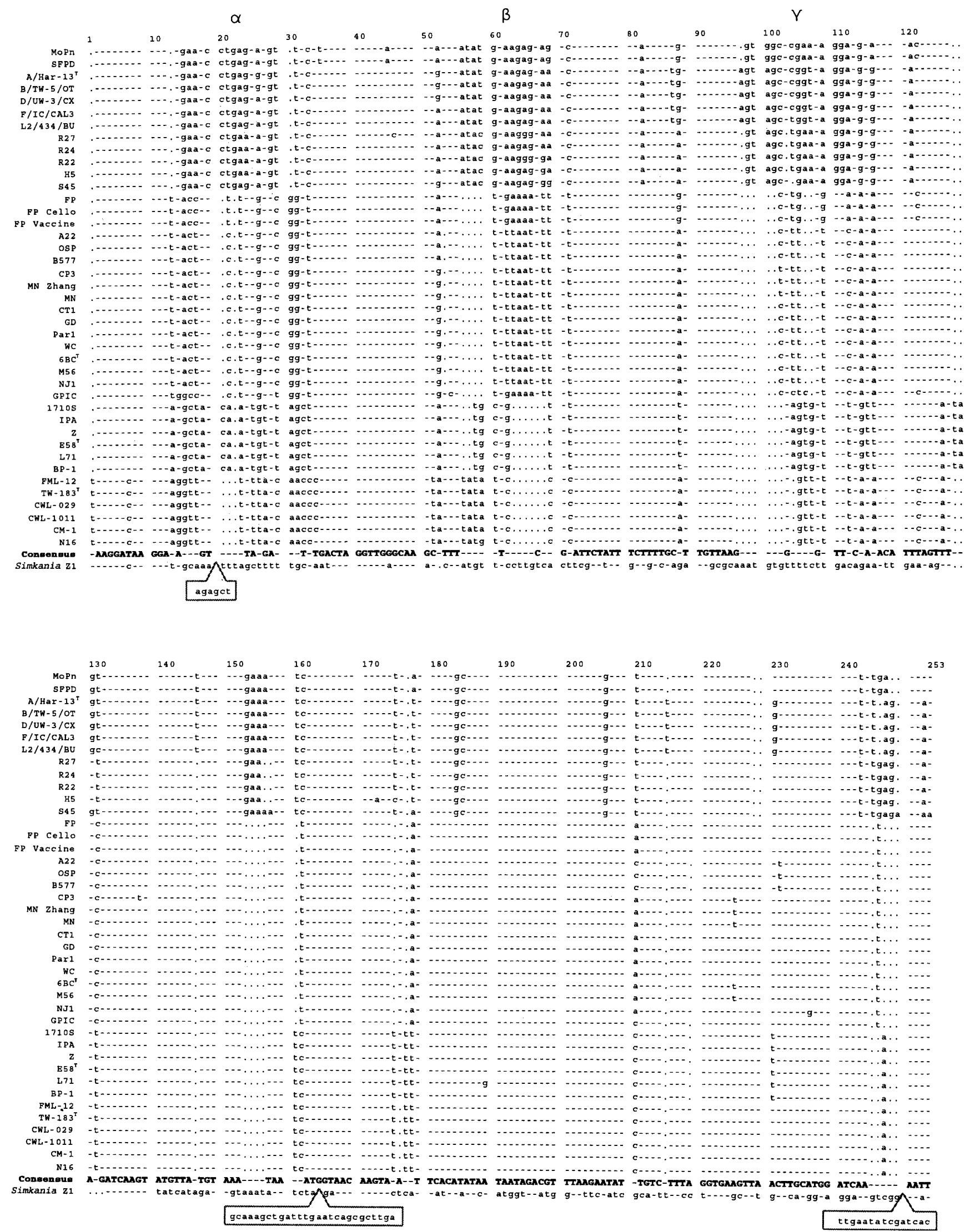

FIG. 2. DNA sequence comparison of the $16 \mathrm{~S} / 23 \mathrm{~S}$ ribosomal intergenic spacers from chlamydiae and the nearest relative. Dots indicate gaps in the alignment, and dashes indicate identity with the consensus sequence displayed below the alignment. Consensus was defined as 28 or more base identities at a position. The intergenic spacer sequence of Simkania sp. strain "Z1," the most closely related known organism, is shown below the consensus sequence. Highly variable segments are designated $\alpha, \beta$, and $\gamma$. Strain FML-16 was identical to TW-183 ${ }^{\mathrm{T}}$. Strain EBA (an epizootic bovine abortion strain) was identical to A22 and OSP. 
TABLE 2. Differences between chlamydial groups

\begin{tabular}{|c|c|c|c|c|c|c|c|c|c|c|}
\hline \multirow[b]{2}{*}{ Sequence } & \multirow{2}{*}{ Group $^{a}$} & \multicolumn{9}{|c|}{$\%$ Difference ${ }^{b}$} \\
\hline & & $\begin{array}{l}\text { Human } \\
\text { group }\end{array}$ & $\begin{array}{l}\text { Swine } \\
\text { group }\end{array}$ & $\begin{array}{l}\text { Mouse-hamster } \\
\text { group }\end{array}$ & C. pneumoniae & C. pecorum & $\begin{array}{l}\text { Avian } \\
\text { group }\end{array}$ & $\begin{array}{l}\text { Abortion } \\
\text { group }\end{array}$ & $\begin{array}{l}\text { Feline } \\
\text { group }\end{array}$ & $\begin{array}{c}\text { Guinea pig } \\
\text { group }\end{array}$ \\
\hline \multirow[t]{9}{*}{ Intergenic spacer } & Human & $1.0(0.8)$ & & & & & & & & \\
\hline & Swine & $5.3(0.5)$ & $1.9(1.0)$ & & & & & & & \\
\hline & Mouse-hamster & $5.8(0.4)$ & $6.2(0.9)$ & $0.0(0.0)$ & & & & & & \\
\hline & C. pneumoniae & $24.2(0.4)$ & $22.9(0.9)$ & $23.0(0.3)$ & $0.3(0.4)$ & & & & & \\
\hline & C. pecorum & $22.1(0.4)$ & $21.6(0.7)$ & $23.1(0.3)$ & $11.8(0.5)$ & $0.2(0.2)$ & & & & \\
\hline & Avian & $23.3(0.9)$ & $22.3(0.8)$ & $23.4(0.7)$ & $13.8(0.5)$ & $13.8(0.4)$ & $0.7(0.5)$ & & & \\
\hline & Abortion & $23.6(0.6)$ & $22.1(0.5)$ & $23.0(0.0)$ & $12.9(0.2)$ & $12.9(0.2)$ & $1.8(0.5)$ & $0.0(0.0)$ & & \\
\hline & Feline & $20.3(0.6)$ & $19.8(0.6)$ & $18.6(0.0)$ & $13.4(0.2)$ & $13.4(0.2)$ & $5.6(0.5)$ & $5.6(0.0)$ & $0.0(0.0)$ & \\
\hline & Guinea pig & $22.9(0.6)$ & $22.7(0.8)$ & $21.5(0.0)$ & $13.4(0.3)$ & $13.9(0.2)$ & $5.6(0.5)$ & $5.6(0.0)$ & $5.6(0.0)$ & $0.0(0.0)$ \\
\hline \multirow[t]{9}{*}{ Domain I } & Guinea pig & $16.7(0.1)$ & $15.6(0.4)$ & $15.9(0.0)$ & $6.8(0.2)$ & $8.8(0.2)$ & $4.3(0.1)$ & $4.9(0.1)$ & $4.2(0.1)$ & $0.0(0.0)$ \\
\hline & Feline & $16.8(0.1)$ & $16.6(0.3)$ & $16.3(0.2)$ & $6.1(0.2)$ & $7.8(0.2)$ & $3.5(0.2)$ & $3.9(0.1)$ & $0.1(0.1)$ & \\
\hline & Abortion & $17.2(0.1)$ & $17.3(0.1)$ & $16.5(0.2)$ & $6.0(0.2)$ & $6.5(0.2)$ & $1.6(0.2)$ & $0.1(0.1)$ & & \\
\hline & Avian & $16.6(0.1)$ & $16.7(0.1)$ & $15.9(0.1)$ & $5.9(0.3)$ & $7.0(0.2)$ & $0.5(0.3)$ & & & \\
\hline & C. pecorum & $18.0(0.2)$ & $18.0(0.2)$ & $17.8(0.2)$ & $6.1(0.3)$ & $0.2(0.2)$ & & & & \\
\hline & C. pneumoniae & $18.0(0.2)$ & $15.5(0.3)$ & $15.5(0.3)$ & $0.5(0.4)$ & & & & & \\
\hline & Mouse-hamster & $15.9(0.3)$ & $5.7(0.6)$ & $0.0(0.0)$ & & & & & & \\
\hline & Swine & $4.7(0.1)$ & $1.2(1.0)$ & & & & & & & \\
\hline & Human & $0.4(0.2)$ & & & & & & & & \\
\hline
\end{tabular}

"The human, swine, and mouse-hamster groups are currently classified as C. trachomatis groups. The avian, abortion, feline, and guinea pig groups are currently classified as $C$. psittaci groups.

${ }^{b}$ The values are means (standard deviations from the means) determined by using all of the strains in each group (Table 1).

Nucleotide sequence accession numbers. DNA sequence data for the ribosomal segments described in this paper have been deposited in the GenBank database under accession numbers U68419 through U68460, U76710, and U76711.

\section{RESULTS}

Characterization of sequence diversity in a 2.8 -kb portion of the ribosomal operon. The 2.8 -kb cloned ribosomal PCR products from two Chlamydia strains, swine strain R22 and turkey strain NJ1, contained approximately one-third of the $16 \mathrm{~S}$ gene, the intergenic spacer, and two-thirds of the $23 \mathrm{~S}$ gene. A comparison of the two sequences is shown in Fig. 1A. The 23S gene start site (TACAGACCAAGT. . ) was located four bases upstream of the homologous Escherichia coli site (data not shown). The $5^{\prime}$ ends of the 2.8 -kb segments each contained 563 bp of DNA homologous to $16 \mathrm{~S}$ gene sequences that differed from each other by only $3 \%$. A search of the GenBank database performed with the $16 \mathrm{~S}$ gene segments indicated that R22 was most closely related to $C$. trachomatis and $\mathrm{NJ} 1$ was most closely related to $C$. psittaci. The $16 \mathrm{~S} / 23 \mathrm{~S}$ intergenic spacer sequences of R22 and NJ1 were 243 and 224 bp long, respectively, and differed by $22.0 \%$. The 1,960 -base $23 \mathrm{~S}$ gene segments differed by $9.6 \%$. Much of the variation in the $23 \mathrm{~S}$ segment was in the $5^{\prime}$ end homologous to domain I of the $E$. coli $23 \mathrm{~S}$ gene. The domain I sequences of R22 and NJ1 (622 and $621 \mathrm{bp}$, respectively) differed by $17 \%$, while the remaining portions of the $23 \mathrm{~S}$ segments $(1,338 \mathrm{bp})$ varied by $6.4 \%$. No intragenic spacers were identified within the chlamydial $23 \mathrm{~S}$ genes.

TABLE 3. Differences within chlamydial groups

\begin{tabular}{|c|c|c|c|c|c|}
\hline \multirow{3}{*}{ Taxon } & \multicolumn{4}{|c|}{$\%$ rDNA difference } & \multirow{3}{*}{$\operatorname{Strain}(s)^{c}$} \\
\hline & \multicolumn{2}{|c|}{ Intergenic spacer } & \multicolumn{2}{|c|}{ Domain I } & \\
\hline & Mean $^{a}$ & Maximum $^{b}$ & $\operatorname{Mean}^{a}$ & Maximum $^{b}$ & \\
\hline Chlamydia spp. & 13.56 & 24.91 & 9.39 & 18.43 & \\
\hline C. trachomatis & 4.22 & 6.64 & 3.26 & 6.91 & \\
\hline Human group & 1.00 & 2.10 & 0.38 & 0.64 & $\mathrm{~A} / \mathrm{Har} 13^{\mathrm{T}}, \mathrm{B} / \mathrm{TW}-5 / \mathrm{OT}, \mathrm{D} / \mathrm{UW}-3 / \mathrm{CX}, \mathrm{F} / \mathrm{IC} / \mathrm{CAL} 3, \mathrm{~L} 2 / 434 / \mathrm{BU}$ \\
\hline Mouse-hamster group & 0.0 & 0 & 0.0 & 0 & MoPn, SFPD \\
\hline Swine group & 1.89 & 3.47 & 1.19 & 2.62 & H5, R22, R24, R27, S45 \\
\hline C. psittaci & 2.73 & 6.62 & 2.06 & 4.99 & \\
\hline Avian group & 0.65 & 1.82 & 0.45 & 0.81 & 6BC ${ }^{\mathrm{T}}, \mathrm{CP} 3, \mathrm{CT} 1, \mathrm{GD}, \mathrm{M} 56, \mathrm{MN}$ VR 122, MN Zhang, NJ1, Parl, WC \\
\hline Abortion group (sheep, cattle) & 0.0 & 0 & 0.11 & 0.16 & $\mathrm{~A} 22, \mathrm{~B} 577, \mathrm{EBA}, \mathrm{OSP}$ \\
\hline $\begin{array}{l}\text { Feline group } \\
\text { Guinea pig group }\end{array}$ & 0.0 & 0 & 0.11 & 0.16 & $\begin{array}{l}\text { FP, FP Cello, FP Vaccine } \\
\text { GPIC }\end{array}$ \\
\hline $\begin{array}{l}\text { Guinea pig group } \\
\text { C. pneumoniae (human, horse) }\end{array}$ & 0.30 & 0.91 & 0.54 & 1.30 & $\begin{array}{l}\text { GPIC } \\
\text { CM-1, CWL-1011, CWL-029, FML-12, FML-16, N16, TW-183'T }\end{array}$ \\
\hline C. pecorum (sheep, swine, cattle) ${ }^{e}$ & 0.15 & 0.45 & 0.16 & 0.49 & 1710S, BP-1, E58 ${ }^{\mathrm{T}}$, IPA, L71, Z \\
\hline
\end{tabular}

${ }^{a}$ Mean based on Jukes-Cantor corrected distances

${ }^{b}$ Maximum difference between any two strains in each group.

c Isolated mammalian epizootics were associated with strains M56, MN VR 122, MN Zhang, and WC.

${ }^{d}$ Only one guinea pig isolate is available.

${ }^{e}$ Koala isolates were not available for this study. 
TABLE 4. Variation within ompl and ribosomal sequences

\begin{tabular}{llcr}
\hline \multicolumn{1}{c}{$\begin{array}{c}\text { Segment or } \\
\text { gene }^{a}\end{array}$} & $\begin{array}{c}\text { \% Identical } \\
\text { positions for } \\
\text { all strains }\end{array}$ & $\begin{array}{c}\text { \% Identical posi- } \\
\text { tions for two-thirds } \\
\text { or more of the strains }\end{array}$ & $\begin{array}{c}\text { No. of } \\
\text { strains }\end{array}$ \\
\hline ompl nucleotides & $40(47)^{b}$ & $72(80)$ & 34 \\
ompl amino acids & $50(67)$ & $70(89)$ & 34 \\
Intergenic spacer & 56 & 75 & 41 \\
Domain I & 74 & 91 & 41 \\
16S $^{c}$ & 91 & 97 & 4 \\
\hline
\end{tabular}

${ }^{a}$ Data for only five human C. trachomatis strains from the GenBank database or from previously published papers were included. $16 \mathrm{~S}$ data for three of the four currently recognized species were included.

${ }^{b}$ The values in parentheses are the values obtained when the variable domains were not included.

${ }^{c}$ The strains used were $C$. psittaci $6 \mathrm{BC}^{\mathrm{T}}$, C. trachomatis $\mathrm{L} 2 / 434 / \mathrm{BU}, C$. pneumoniae $\mathrm{TW}-183^{\mathrm{T}}$, and $C$. pecorum $\mathrm{E} 58^{\mathrm{T}}$.

Ribosomal sequence analysis of $\mathbf{4 3}$ Chlamydia strains. Based on the results of the sequence analysis of the $2.8-\mathrm{kb}$ portion of the ribosomal operons of strains $\mathrm{R} 22$ and $\mathrm{NJ} 1$, a highly variable 1,320-bp ribosomal DNA (rDNA) segment flanked by conserved regions was identified (Fig. $1 \mathrm{~A}$ and $\mathrm{B}$ ). The sequence of this segment was determined for an additional 41 Chlamydia strains and two chlamydia-like organisms, Simkania sp. strains "Z" and "Z1" (Table 1). To establish whether the sequences of cloned PCR products and directly sequenced PCR products were comparable, more than 10,000 bp was examined by using both types of template. Only four base differences between cloned sequence and direct PCR product sequence were found. In each of these cases, the sequence of the PCR product, which represented a broader sample of ribosomal operons than a single clone, was selected as the final sequence. No ambiguous sequence data were obtained for the C. trachomatis sequences that were obtained from both cloned and direct PCR products. (If a high proportion of nonidentical ribosomal operons were present in any single isolate, ambiguous data would have been generated from the PCR product template.) A comparison of the sequences of the 43 strains indicated that the sequences clustered into nine groups. The differences among strains representing the nine groups are shown in Fig. 1B.

Analysis of the ribosomal intergenic spacer. The $16 \mathrm{~S} / 23 \mathrm{~S}$ intergenic spacer sequences of the chlamydiae identified in Table 1 are shown as a multiple-sequence alignment in Fig. 2. The intergenic spacers spanned $232 \pm 11$ bases depending on the strain. Nine single-base differences were unique to only one or two strains, and approximately 80 sequence position differences were group clustered and conserved in species, subspecies, or several species. Among these 80 positions were three highly variable segments, each approximately $20 \mathrm{bp}$ long (Fig. $2, \alpha, \beta$, and $\gamma$ segments), between base 12 and base 115 that were distinctly group cluster specific. An RNAfold-Squiggles analysis of the intergenic spacer indicated that each of the $\alpha$ segments could form a hairpin structure with a 10-bp stem centered between bases 23 and 24 (analyses not shown). The Simkania sp. strain "Z1" intergenic spacer was 44 bases longer than the longest chlamydial intergenic spacer (Fig. 2).

To determine whether sequence conservation in the chlamydial intergenic spacer could be correlated with the $E$. coli model of rRNA processing, the rDNA sequence flanking the $5^{\prime}$ end of the $16 \mathrm{~S}$ gene from chlamydial strain MoPn was obtained from the GenBank database and spliced, by computer, to the MoPn intergenic spacer sequence that was determined in this study. In $E$. coli, homologous rRNA segments form a stemloop structure to facilitate nucleolytic processing of the $16 \mathrm{~S}$
rRNA. An RNA sequence analysis of the spliced segments performed with the RNAfold and Squiggles programs showed that the two MoPn segments complemented each other, forming a 45-base stem (Fig. 3). The MoPn 5' flanking segment has been shown to contain rRNA start sites P1 and P2 (19). The complementary stem shown in Fig. 3 contained the P2 rRNA processing site and highly conserved segments of the intergenic spacer adjacent to the $\alpha$ segment.

A parsimony analysis by heuristic search performed with PAUP, version 3.1, was used to construct a phylogenetic tree based on the intergenic spacers (Fig. 4). The shortest tree required 135 steps for the 254 bases. The intergenic spacer tree was midpoint rooted for appearance. This analysis separated the chlamydiae into the following two distinct lineages: the $C$. trachomatis lineage, which included strains isolated from humans, swine, a mouse, and a hamster; and the non- $C$. trachomatis lineage, which included $C$. psittaci, $C$. pecorum, and $C$. pneumoniae. The $C$. trachomatis sequences clustered in a hostspecific manner, with the human isolates the greatest distance (greatest number of sequence changes) from the common node. The non-C. trachomatis sequences were subdivided into six groups, and within each group the strains at the tips of the branches were essentially indistinguishable. Two of the six groups, $C$. pneumoniae and $C$. pecorum, diverged from a common node, while the remaining four groups (all $C$. psittaci) diverged from a separate node. The members of two of the $C$. psittaci groups (abortion and feline) exhibited no sequence variation, while the members of the avian $C$. psittaci group exhibited a small amount of sequence variation. Bootstrap resampling of the data revealed a high degree of confidence in the branching order.

Distance analysis of the intergenic spacer and the $23 \mathrm{~S}$ domain I segment. A comparison of the intergenic spacers showed that there were 143 positions $(56.1 \%$ of the sequence positions) at which the bases were identical in all chlamydial strains; 28 or more strains had the same base at $75.1 \%$ of the positions in the sequence. The $C$. trachomatis intergenic spacers differed by $\geq 18 \%$ from those of all of the other strains (Table 2). C. pneumoniae and C. pecorum intergenic spacers differed from $C$. psittaci intergenic spacers by $13.3 \% \pm 1 \%$ (mean \pm standard error of the mean) and by $11.8 \% \pm 0.5 \%$ from each other. When the intergenic spacer sequences were used to cluster the organisms into the nine genetically related groups, the standard deviation from the mean within each group or between any two groups was $\leq 1.0 \%$. The mean of the pairwise differences within most of the groups was also $\leq 1.0 \%$; the only exception was the swine group (swine strain S45 differed by $3.0 \% \pm 0.5 \%$ from other swine strains) (Tables 2 and 3 ). The difference between the abortion and avian groups was $1.8 \% \pm 0.5 \%$, a value slightly less than the $1.9 \% \pm 1.0 \%$ difference within the swine group. This closeness indicated that, for the intergenic spacer, an approximately $2 \%$ mean difference could be considered a threshold between group and subgroup designations. All other groups were at least $5.3 \%$ different from each other. The mean of intergenic spacer differences overall was $13.56 \%$, with the largest difference being $24.91 \%$ and the smallest difference being $0 \%$ (Table 3). The Simkania intergenic spacer differed from Chlamydia intergenic spacers by 89 to $96 \%$. The chlamydial distance data were used to produce an intergenic spacer tree by the neighbor-joining method (data not shown). This tree preserved the relationships between the clusters that were present in the parsimony tree in Fig. 4.

For the domain I segments, the bases at 460 positions ( $74.2 \%$ of the sequence positions) were identical in all chlamydial strains. At least 28 strains were identical at $90.7 \%$ of the 


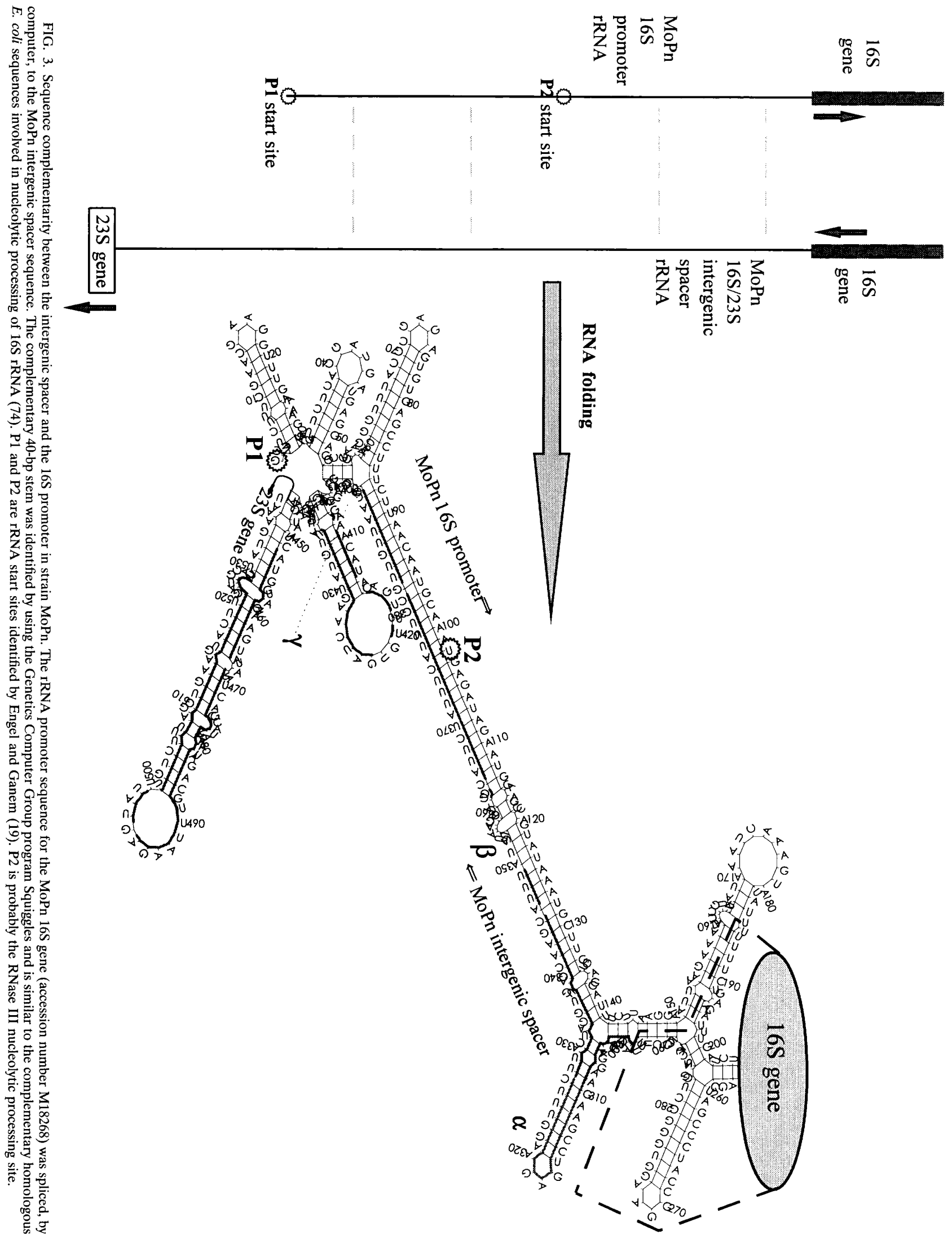




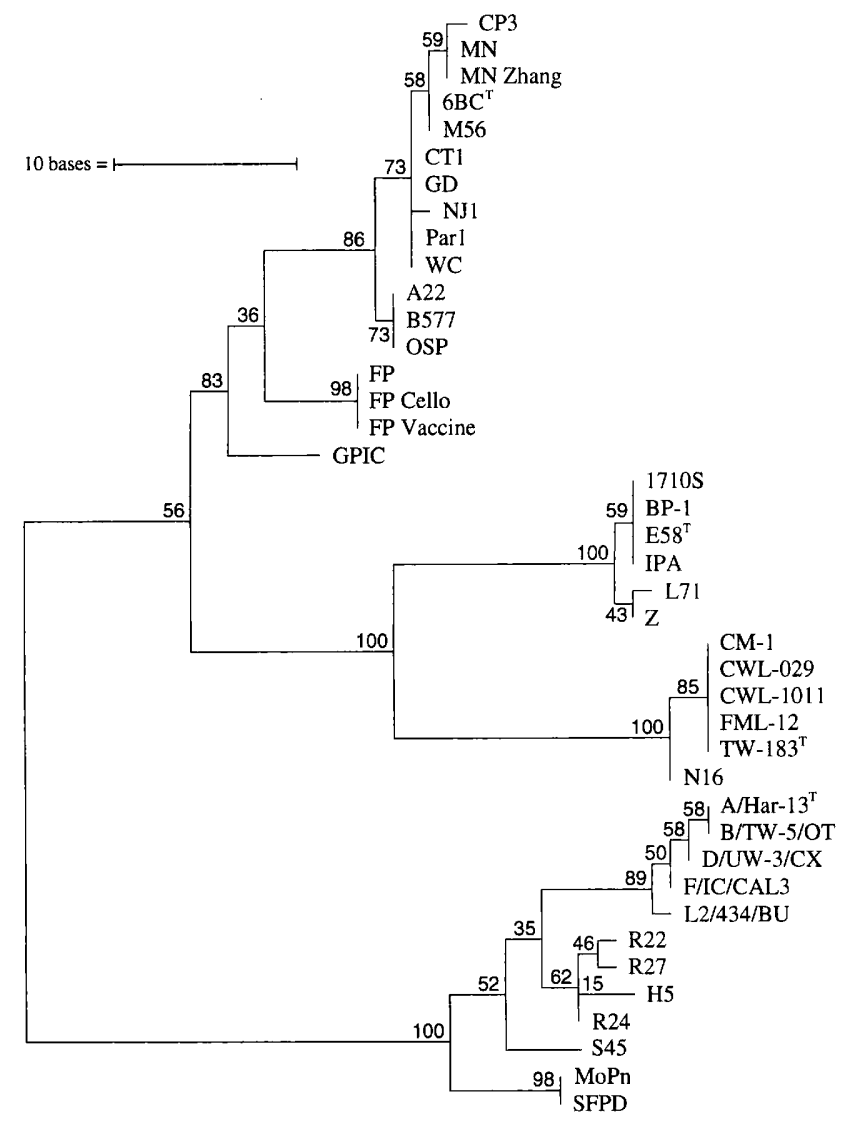

FIG. 4. Most parsimonious consensus tree based on the intergenic spacers of chlamydial strains $(232 \pm 11 \mathrm{bp})$. The numbers are bootstrap values, which were determined by 100 bootstrap resampling replications (values approaching 100 indicate high branching order reliability). The horizontal branch lengths are proportional to the numbers of nucleotides that differ between nodes or clusters. Tree bisection-reconnection branch swapping was employed. This unrooted tree is a consensus tree based on the seven most parsimonious trees, which differed only in the specific arrangement of strains R22, R24, R27, and H5 within the swine cluster. Strain FML-16 was identical to TW-183 ${ }^{\mathrm{T}}$. Strain EBA was identical to A22 and OSP.

positions in the sequence. The domain I segments of the $C$. trachomatis strains differed by $\geq 15 \%$ from the domain I segments of all of the other isolates (Table 2). C. pecorum and C. psittaci differed from $C$. pneumoniae by $6.7 \% \pm 1.3 \%$ and differed from each other by $7.6 \% \pm 1.4 \%$. When the domain I sequences were clustered into the nine genetically distinct groups, the standard deviation from the mean within each group or between any two groups was $\leq 1.0 \%$. The mean differences within most groups were $\leq 0.5 \%$; the only exception was the swine group (swine strain S45 differed by $2.5 \% \pm 0.2 \%$ from other swine strains) (Tables 2 and 3). The difference between the abortion and avian groups was $1.6 \% \pm 0.2 \%$, a value only slightly greater than the $1.2 \% \pm 1.0 \%$ difference within the swine group. This closeness indicated that an approximately $1.5 \%$ difference in domain I could be considered a threshold between group and subgroup designations. All other groups were at least $3.5 \%$ different from each other. The mean of the domain I differences overall was $9.39 \%$, with the largest difference being $18.43 \%$ and the smallest difference being $0 \%$ (Table 3). The difference between domain I of a Simkania strain and domain I of any single Chlamydia strain was $\geq 26 \%$. The differences between domain I of an outgroup, Pirellula marina, which has an unlinked operon, and domain I of Chla- mydia and Simkania strains were 39 to $46 \%$. These distance data were used to produce trees by the neighbor-joining method, by Fitch analysis, and by maximum-likelihood analysis (data not shown). These trees preserved the relationships between the clusters that are shown in the parsimony tree in Fig. 5.

The variations in chlamydial intergenic spacers, domain I segments, 16S genes (from GenBank), and ompl sequences (from GenBank or from previously published papers) are shown in Table 4. Domain I and the intergenic spacer were each more conserved than ompl, even when ompl variable domains were eliminated from the analysis. The $16 \mathrm{~S}$ gene was more conserved than the intergenic spacer or domain I.

Phylogenetic analysis of domain I of the $23 S$ gene. Domain I was the most variable $23 \mathrm{~S}$ gene segment, and differences grouped chlamydial strains into species- or subspecies-specific groups. Domain I, which spanned $620 \pm 2$ bp depending on the strain, was used for a phylogenetic analysis by a heuristic search in which PAUP, version 3.1, was used (Fig. 5). The shortest tree required 493 steps over 638 nucleotides. The domain I tree was rooted with the genus Simkania and the planctomycete $P$. marina (accession number X07408). P. marina was more distantly related than the genus Simkania. This analysis showed that the chlamydiae are separated into two lineages, a $C$. trachomatis lineage and a non-C. trachomatis lineage. The non- $C$. trachomatis lineage diverged furthest from the common node. The $C$. trachomatis lineage included three host-specific groups: human, swine, and mouse-hamster groups. The mouse-hamster group was the group that diverged the least from the common $C$. trachomatis node, while the swine group had the most sequence differences compared with the common node. The non-C. trachomatis lineage diverged into six groups: a $C$. pneumoniae group, a $C$. pecorum group, and $C$. psittaci abortion, avian, feline, and guinea pig groups. C. psittaci avian isolates included epizootic isolates from mammalian hosts. Bootstrap resampling of the data revealed a high degree of confidence in the branching order.

\section{DISCUSSION}

In this study we established that PCR and DNA sequence analysis of the intergenic spacer and domain I in the chlamydial ribosomal operon is a reliable and easy way to classify and identify species and other groups of Chlamydia spp. The following conclusions were drawn: (i) the genus Chlamydia is a monophyletic group with two branched lineages; (ii) the $C$. trachomatis lineage includes three distinct groups, and the non-C. trachomatis lineage includes six distinct groups; (iii) most Chlamydia groups are specifically adapted to certain hosts; (iv) chlamydial groups identified by using other techniques are consistent with the two lineages and nine groups; (v) the intergenic spacer and/or domain I of Chlamydia strains may be used as a foundation for phylogenetic analysis because each sequence is functionally conserved and subject to systematic selective pressures; and (vi) sequence analysis of the segments provides a legitimate and unambiguous way to taxonomically identify and classify chlamydial strains.

Conserved oligonucleotide primers for the $16 \mathrm{~S}$ gene and for the 23S gene were used to PCR amplify a 2.8 -kb segment of the ribosomal operon from 43 Chlamydia strains and from Simkania sp. strains " $\mathrm{Z}$ " and " $\mathrm{Z1}$ " for sequence analysis. A complete DNA sequence analysis of this segment from two strains, $C$. trachomatis swine strain R22 and C. psittaci turkey strain NJ1, revealed that the $16 \mathrm{~S} / 23 \mathrm{~S}$ intergenic spacer and domain I of the $23 \mathrm{~S}$ gene (homologous to domain I of the E. coli $23 \mathrm{~S}$ gene) had potential for differentiating species, as they exhibited 22 


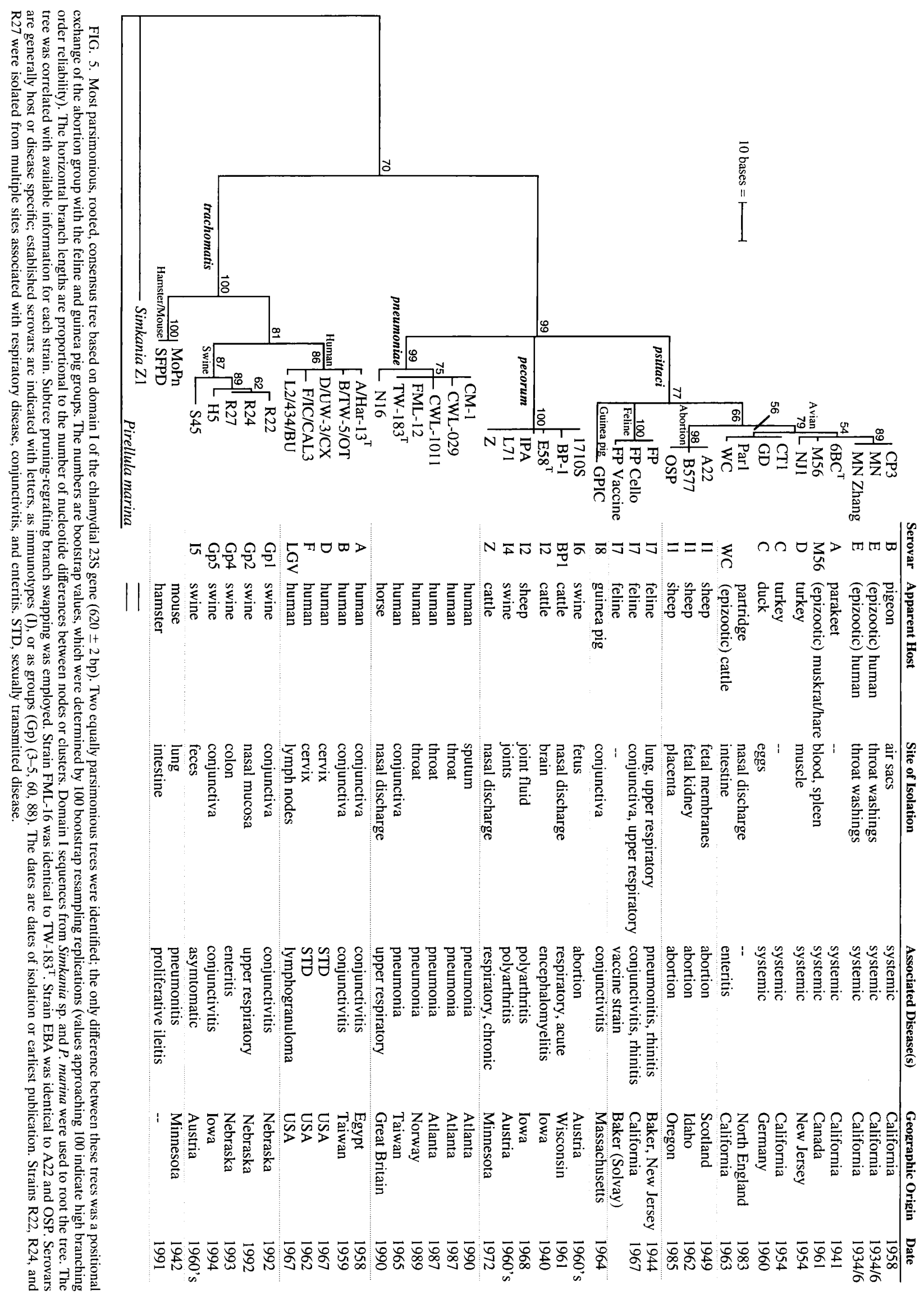


and $17 \%$ diversity, respectively. The sequence of a $1,320-\mathrm{bp}$ segment containing the intergenic spacer ( $232 \mathrm{bp}$ ) and domain I ( $620 \mathrm{bp})$ was determined for each of the strains. Separate analyses of the intergenic spacer and domain I were performed because the two sequences coded for different gene functions, each sequence exhibited substantial genetic diversity, and each region was a short, concise segment whose sequence was easily determined. The intergenic spacer and domain I sequences were subjected to a character analysis by using the PAUP program, and the most parsimonious consensus trees were produced (Fig. 1 and 4). The groups identified on the tree based on the intergenic spacer were nearly identical to the groups on the rooted tree based on domain I. When the same sequences were subjected to a distance analysis (Tables 2 and 3 ), the results were essentially identical to the results obtained when PAUP was used. These ribosomal trees were congruent with phylogenetic trees based on omp1 $(15,22,44,80,97), 16 \mathrm{~S}$ gene (1a, 43, 62a), and DNA reassociation (44) data.

Rooting the Chlamydia domain I tree with $P$. marina (the most closely related planctomycete) and with the genus Simkania showed that all Chlamydia strains evolved from a common ancestor and diverged at a node located between the $C$. trachomatis lineage and the non-C. trachomatis lineage (Fig. 5). This early separation of $C$. trachomatis is supported by biological evidence $(50,56)$. Similarities between the $C$. trachomatis and non- $C$. trachomatis lineages indicate that the common ancestor would have had the typical chlamydial group antigen (lipopolysaccharide), rough phenotype, cell wall structure, genome size (20), ribosomal operon structure, and obligately host-dependent growth cycle. Rooting of the 16S gene has provided further evidence that $C$. trachomatis diverged from non-C. trachomatis taxa (43). This bipolar divergence was also evident in phylogenetic studies based on ompl $(22,44,97)$, omp2 (envB) (22), and the intergenic spacer (Fig. 4); however, confirmation by rooting has not been possible because outgroup sequences with significant homology have not been identified. A lack of DNA-DNA homology $(17,25,44)$ indicates that these lineages differ sufficiently to be considered separate genera (71).

The genus Simkania is a bacterial taxon that shares characteristics with the chlamydial common ancestor; it has a similar ribosomal operon, morphology, and obligately host-dependent growth cycle. This makes the genus Simkania an appropriate root for a phylogenetic investigation of the genus Chlamydia. Simkania sp. strain "Z," a cell culture contaminant whose $16 \mathrm{~S}$ gene (accession number L27666) is only 18\% different from the chlamydial $16 \mathrm{~S}$ gene (43), has inner and outer membranes which morphologically resemble membranes of Chlamydia spp. Simkania sp. strain "Z1", which was isolated by Kahane as a possible subgroup of " $\mathrm{Z}$," was indistinguishable from " $\mathrm{Z}$ " in our study. Identifying a next-closest root for the genera Chlamydia and Simkania is more difficult because the branching order within the domain Bacteria is largely unresolved $(1,10)$. However, Van de Peer et al. have suggested that the genus Planctomyces probably diverged prior to the branching of the genus Chlamydia and the other 15 eubacterial lineages (86). This suggests that $P$. marina shares an ancestor with the genera Simkania and Chlamydia and nearly all other eubacteria. A relationship between the genera Planctomyces and Chlamydia was supported by the results of a higher-order structure analysis of the $16 \mathrm{~S}$ gene (90). Unlike the chlamydiae, $P$. marina has an unlinked ribosomal operon with more than $7 \mathrm{~kb}$ separating the $16 \mathrm{~S}$ and $23 \mathrm{~S}$ genes (75). The $16 \mathrm{~S}$ gene sequence of $P$. marina differs by $35 \%$ from the sequences of Simkania and Chlamydia strains, and the $23 \mathrm{~S}$ genes of $P$. marina and Chlamydia spp. are $40 \%$ different (91). Planctomycetes are free- living organisms, and at least one has a genome that is five times larger than the chlamydial genome (89).

On the basis of the results of an analysis of the intergenic spacer and domain I we identified nine phylogenetic groups in the two chlamydial branches, many of which could be readily distinguished by host specificity. The $C$. trachomatis taxon included three groups, one specific for human hosts, one specific for mouse-hamster hosts, and one specific for swine hosts. $C$. trachomatis human strains have been isolated from humans with trachoma or sexually transmitted disease. They are clustered into 18 serovars (11) and are closely related as determined by omp1 analyses $(22,97)$, omp 2 analysis $(22)$, intergenic spacer analyses (Tables 2 and 3 and Fig. 4), and domain I sequence analyses (Tables 2 and 3 and Fig. 5). Worldwide, these serovars exhibit only minor epidemiological differences, which are identifiable by ompl analysis. The $C$. trachomatis mouse-hamster group is also host specific, having been isolated only from members of the family Muridiae. Members of this group have been isolated from animals with respiratory infections or proliferative ileitis, and their ompl sequences are divergent (97). The $C$. trachomatis swine group has only recently been characterized and appears to be specific for swine. The strains in this group have been associated with conjunctivitis, enteritis, and pneumonia $(5,44,66,67)$.

The non-C. trachomatis taxon is comprised of six genotypic groups that are currently designated C. psittaci, C. pneumoniae, and $C$. pecorum. The $C$. psittaci feline pneumonitis group is endemic in cats, causing mucosal infections with predominately upper respiratory tract symptoms $(28,69)$. Whether they were identified in the 1940s, in the 1990 s, or in different parts of the world, feline pneumonitis isolates are serologically the same and have identical omp1 restriction endonuclease patterns (69). The $C$. psittaci guinea pig inclusion conjunctivitis group, for which only a single isolate has been identified, has not been recovered from hosts other than the guinea pig. The $C$. psittaci avian group includes eight serovars. Serovars A and $\mathrm{B}$ are endemic in psittacine birds and pigeons, respectively. The other avian serovars have been isolated from members of more than one avian family or include only a limited number of isolates, and so the natural hosts of these serovars are not yet known. $C$. psittaci avian infections are often systemic and are either acute, inapparent, severe, or chronic with intermittent shedding. All C. psittaci avian isolates are similar in virulence and growth characteristics in cell culture. They appear to be uniquely susceptible to bacteriophage Chp1 (79). Sporadic human infection and illness following exposure to birds harboring C. psittaci avian strains have been widely documented. Isolates WC, M56, MN VR 122, and MN Zhang were obtained from sporadic infections of humans or other mammals $(23,55,73$, 98). Strains WC and M56 evidently have not reappeared since the original outbreaks, while $\mathrm{MN}$ strains have been isolated repeatedly from birds. The $C$. psittaci abortion group is endemic in ruminants. Some strains have been observed to cause sporadic abortion in women who are sheep handlers (40). Abortion strains are highly invasive in placental tissue (63) and belong to a serovar that has been obtained from sheep, cattle, and goats worldwide $(3,18,82)$. In the past, there was some confusion in classifying chlamydiae because preparation A22/M of ovine abortion strain A22 was evidently contaminated with an avian strain. Sequence analysis has shown that A22/M omp1 (accession number X12647) is identical to duck strain Avn352 omp1 (accession number L04980) and to MN strain VR $122 \mathrm{ompl}$ (20). A22/M ompl is not identical to ovine A22 omp1 (39).

Neither $C$. pneumoniae nor $C$. pecorum is limited to a specific host. $C$. pneumoniae strains have been isolated from hu- 
mans, horses, and koalas $(31,46,80)$. They are associated with respiratory disease, severe systemic infection, coronary artery disease, and ocular disease $(32,46)$. Human $C$. pneumoniae isolates are serologically nearly indistinguishable (46), and human omp1 differs from both horse omp1 and koala omp1. C. pecorum strains have been isolated from ruminants (cattle, goats, and sheep), koalas, and swine, so they, too, are not host specific $(8,18,26,32)$. C. pecorum is uniquely noninvasive in a mouse model of virulence (65). These strains are pathogenically and serologically diverse, having a disease range that includes abortion, conjunctivitis, encephalomyelitis, enteritis, pneumonia, and polyarthritis $(8,44)$.

The results obtained in this study are consistent with chlamydial groups determined by other methods. DNA-DNA reassociation studies of chlamydiae have indicated that the eight groups that have been studied are all less than $70 \%$ homologous and therefore qualify as separate species $(1,17,25,44,71$, 76). The $C$. psittaci avian and abortion groups were the most closely related groups as determined by the intergenic spacer and domain I analysis and also by the DNA-DNA homology analysis. The four current species were the most distantly related taxa as determined by the intergenic spacer and domain I analysis and also by DNA-DNA homology analysis. The genomic endonuclease restriction technique is also used to distinguish species (85). This technique has identified the nine Chlamydia groups: $C$. trachomatis human group (61), a mouse group $(25,61)$, a swine group (20), an avian group $(2,6,33,48)$, an abortion group $(40,47,64)$, a feline group $(25,33,40,48)$, a guinea pig inclusion conjunctivitis group (14), C. pecorum $(8$, $25,84)$, and $C$. pneumoniae $(14,33)$. The distinct separation of these nine groups is supported by the results of phylogenetic analyses of omp1 $(15,22,44,80,97)$.

The intergenic spacer and/or domain I may be used as a basis for phylogenetic analysis because each of these regions is subject to systematic selective pressure and functional conservation. For a classification system to be dependable, only gene sequences that are under comparable selective pressures (i.e., sequences that perform identical functions) may be compared (95). Intergenic spacers function in nucleolytic processing of rRNA genes by formation of complementary stem-loops with the $16 \mathrm{~S}$ promoter region and with the segment downstream of the $23 \mathrm{~S}$ gene (74). In this study, chlamydial intergenic spacers were found to be highly conserved with well-defined segments of species- or group-specific sequence and no tRNA genes (Fig. 2). A conserved segment of the $C$. trachomatis MoPn intergenic spacer complemented the $16 \mathrm{~S}$ promoter sequence, and nucleolytic processing site P2 (19) was located in the complementary stem (Fig. 3). This suggests that the site of RNase III processing for the $16 \mathrm{~S}$ rRNA is located between variable segments $\beta$ and $\gamma$ of the intergenic spacer. Conservation and complementarity in the intergenic spacers indicate that chlamydiae use these regions in ribosomal processing by a typically eubacterial mechanism and that they are under comparable selective pressures. The sole function of the chlamydial intergenic spacer is to facilitate processing of the $16 \mathrm{~S}$ genes and, presumably, the $23 \mathrm{~S}$ genes. Thus, the intergenic spacer is an appropriate basis for chlamydial classification. Domain I rRNA also meets the criteria for conservation of function as a basis for phylogenetic analysis. The secondary structure of $23 \mathrm{~S}$ rRNA is comprised of six domains with long-range double helices $(1,36)$, and the function of domain I in the $E$. coli ribosome has been characterized (13). Homology between Chlamydia and E. coli domain I sequences indicates that the secondary structures are very similar and that they are therefore likely to have comparable functions (data not shown).

Thus, a new taxonomy for the genus Chlamydia in which the
C. trachomatis and non-C. trachomatis lineages would be separate genera and the nine groups would be species is fully consistent with established taxonomic criteria. Rapid identification and classification could be done by using the intergenic spacer and/or domain I, as the resolving power of these segments is at least equivalent to the resolving power of DNADNA homology. Primers \#16SF2 and \#23R might be used for a preliminary taxonomic assessment (Fig. 1). These primers amplify an approximately 600 -bp PCR product that includes the intergenic spacer and $200 \mathrm{bp}$ of domain I. This product is easily characterized by gel electrophoresis, RFLP analysis, or sequence analysis and is small enough to be efficiently amplified from clinical field specimens or partially intact DNA. In contrast, genus and species determinations based on the $16 \mathrm{~S}$ gene and on ompl would have limitations, as the $16 \mathrm{~S}$ gene lacks diversity and ompl has an excess of diversity (Table 4). The chlamydial $16 \mathrm{~S}$ genes are well-suited for distinguishing Chlamydia spp. and chlamydia-like organisms at the family level. Serological data and omp1 sequences, which are highly variable within each of the nine groups, are ideal for strain identification.

Evolutionary relationships among representative chlamydial isolates from mammals and birds were examined in this study. However, chlamydia-like organisms have now also been identified in the single-celled organism Acanthamoeba sp. (1a, 29). Analyses of domain I segments and 16S genes have indicated that the divergence of chlamydia-like organisms antedated the divergence of the $C$. trachomatis and non- $C$. trachomatis lineages. It is possible that the genus Chlamydia evolved from an ancestor that infected only single-celled organisms and that, as mammals and birds evolved, chlamydiae evolved to fit new niches. Some chlamydial groups, such as the $C$. psittaci avian group, have retained a promiscuous capacity for virulence. The relative inabilities of most other groups to cause endemic disease outside the observed host ranges may be due to adaptation associated with chronic persistence (59) and lack of opportunity. The presence of chlamydia-like organisms in the genus Acanthamoeba and the high degree of adaptation of chlamydial groups to specific hosts indicate that present methods of isolation need to be expanded to encompass more diverse hosts. Techniques for identifying unculturable strains can also greatly broaden our knowledge of the host range of chlamydiae $(1,10)$.

Our results indicate that Chlamydia spp. can be identified by analyzing short DNA segments in the ribosomal operon that contain numerous group-conserved sequence differences. With the information gained, problematic classification issues can be clarified and comprehensive epidemiologic studies can be conducted. The availability of ribosomal data makes possible ordered analysis of relationships among members of the $C$. trachomatis and non- $C$. trachomatis branches of chlamydiae. Ribosomal information developed in this study should facilitate detection and identification of the increasing number of chlamydiae and chlamydia-like organisms.

\section{ACKNOWLEDGMENTS}

We thank Wendy Hamby and Linda Hornung for technical assistance and Neil S. Jensen, Thaddeus B. Stanton, and James Moulder for helpful discussions. We thank Carolyn M. Black, Harlan Caldwell, Lee Ann Campbell, James G. Fox, Alan Herring, Simona Kahane, Bernhard Kaltenboeck, and Christopher Storey for supplying isolates or lysates of chlamydiae and chlamydia-like organisms. We thank Walter M. Fitch and Robin M. Bush for performing the PAUP phylogenetic and bootstrap analyses of the aligned sequences. We also thank William G. Weisburg and Thomas P. Hatch for generously sharing a preprint and for providing nearly complete DNA sequences for the 
23S genes of $C$. psittaci $6 \mathrm{BC}^{\mathrm{T}}, C$. trachomatis $\mathrm{L} 2 / 434 / \mathrm{BU}$, and $C$. pneumoniae TWAR.

\section{REFERENCES}

1. Amann, R. I., W. Ludwig, and K.-H. Schleifer. 1995. Phylogenetic identification and in situ detection of individual microbial cells without cultivation. Microbiol. Rev. 59:143-169.

1a.Amann, R. A., N. Springer, W. Schönhuber, W. Ludwig, E. N. Schmid, K.-D. Müller, and R. Michel. 1997. Obligate intracellular bacterial parasites of acanthamoebae related to Chlamydia spp. Appl. Environ. Microbiol. 63:115121.

2. Andersen, A. A. 1991. Comparison of avian Chlamydia psittaci isolates by restriction endonuclease analysis and serovar-specific monoclonal antibodies. J. Clin. Microbiol. 29:244-249.

3. Andersen, A. A. 1991. Serotyping of Chlamydia psittaci isolates using serovarspecific monoclonal antibodies with the microimmunofluorescence test. J. Clin. Microbiol. 29:707-711.

4. Andersen, A. A. Unpublished data.

5. Andersen, A. A., and D. G. Rogers. 1994. Characterization of Chlamydia psittaci isolates from swine, p. 578-581. In J. Orfila, G. I. Byrne, M. A Chernesky, J. T. Grayston, R. B. Jones, G. L. Ridgway, P. Saikku, J. Schachter, W. E. Stamm, and R. S. Stephens (ed.), Chlamydial infections. Proceedings of the Eighth International Symposium on Human Chlamydial Infections, Bologna, Italy. Study Group for STD and Dermatological Microbiology of the Austrian Society for Dermatology and Venerology, Vienna, Austria.

6. Andersen, A. A., and J. P. Tappe. 1989. Genetic, immunologic, and pathologic characterization of avian chlamydial strains. J. Am. Vet. Med. Assoc. 195:1512-1516

7. Andersen, A. A., and R. A. Van Deusen. 1988. Production and partial characterization of monoclonal antibodies to four Chlamydia psittaci isolates. Infect. Immun. 56:2075-2079.

8. Anderson, I. E., S. I. F. Baxter, S. Dunbar, A. G. Rae, H. L. Philips, M. J. Clarkson, and A. J. Herring. 1996. Analyses of the genomes of chlamydial isolates from ruminants and pigs support the adoption of the new species Chlamydia pecorum. Int. J. Syst. Bacteriol. 46:245-251.

9. Baker, J. A. 1942. A virus obtained from a pneumonia of cats and its possible relation to the cause of atypical pneumonia in man. Science 96:475-476.

10. Barns, S. M., C. F. Delwiche, J. D. Palmer, and N. R. Pace. 1996. Perspectives on archaeal diversity, thermophily and monophyly from environmental rRNA sequences. Proc. Natl. Acad. Sci. USA 93:9188-9193.

11. Batteiger, B. E. 1996. The major outer membrane protein of a single Chlamydia trachomatis serovar can possess more than one serovar-specific epitope. Infect. Immun. 64:542-547.

12. Black, C. M., J. A. Tharpe, and H. Russell. 1992. Distinguishing Chlamydia species by restriction analysis of the major outer membrane protein gene. Mol. Cell. Probes 6:395-400.

13. Bullard, J. M., M. A. van Waes, D. J. Bucklin, and W. E. Hill. 1995. Region of $23 \mathrm{~S}$ ribosomal RNA proximal to transfer RNA bound at the P and E sites. J. Mol. Biol. 252:572-582.

14. Campbell, L. A., C.-C. Kuo, and J. T. Grayston. 1987. Characterization of the new Chlamydia agent, TWAR, as a unique organism by restriction endonuclease analysis and DNA-DNA hybridization. J. Clin. Microbiol. 25:19111916.

15. Carter, M. W., S. A. al-Mahdawi, I. G. Giles, J. D. Treharne, and M. E. Ward. 1991. Nucleotide sequence and taxonomic value of the major outer membrane protein gene of Chlamydia pneumoniae. J. Gen. Microbiol. 137: 465-475.

16. Cello, R. M. 1967. Ocular infections with PLT (Bedsovia) group agents Am. J. Ophthalmol. 63:1270-1273.

17. Cox, R. L., C.-C. Kuo, J. T. Grayston, and L. A. Campbell. 1988. Deoxyribonucleic acid relatedness of Chlamydia sp. strain TWAR to Chlamydia trachomatis and Chlamydia psittaci. Int. J. Syst. Bacteriol. 38:265-268.

18. Denamur, E., C. Sayada, A. Souriau, J. Orfila, A. Rodolakis, and J. Elion. 1991. Restriction pattern of the major outer-membrane protein gene provides evidence for a homogeneous invasive group among ruminant isolates of Chlamydia psittaci. J. Gen. Microbiol. 137:2525-2530.

19. Engel, J. N., and D. Ganem. 1987. Chlamydial rRNA operons: gene organization and identification of putative tandem promoters. J. Bacteriol. 169: $5678-5685$

20. Everett, K. D. E. Unpublished data.

21. Felsenstein, J. 1985. Confidence limits on phylogenies: an approach using the bootstrap. Evolution 39:783-791.

22. Fitch, W. M., E. M. Peterson, and L. M. de la Maza. 1993. Phylogenetic analysis of the outer-membrane-protein genes of chlamydiae, and its implication for vaccine development. Mol. Biol. Evol. 10:892-913.

23. Francis, T., Jr., and T. P. Magill. 1938. An unidentified virus producing acute meningitis and pneumonia in experimental animals. J. Exp. Med. 68: $147-160$.

24. Fraser, C. E. O., and D. T. Berman. 1965. Type-specific antigens in the psittacosis-lymphogranuloma venereum group of organisms. J. Bacteriol. 89:943-948.
25. Fukushi, H., and K. Hirai. 1989. Genetic diversity of avian and mammalian Chlamydia psittaci strains and relation to host origin. J. Bacteriol. 171:28502855.

26. Fukushi, H., and K. Hirai. 1992. Proposal of Chlamydia pecorum sp. nov. for Chlamydia strains derived from ruminants. Int. J. Syst. Bacteriol. 42:306-308.

27. Fukushi, H., and K. Hirai. 1993. Restriction fragment length polymorphisms of rRNA as genetic markers to differentiate Chlamydia spp. Int. J. Syst. Bacteriol. 43:613-617.

28. Gaillard, E. T., A. M. Hargis, D. J. Prieur, J. F. Evermann, and A. S. Dhillon. 1984. Pathogenesis of feline gastric chlamydial infection. Am. J. Vet. Res. 45:2314-2321.

29. Gautom, R., R. Herwig, and T. Fritsche. 1996. Molecular phylogeny of bacterial endosymbionts of Acanthamoeba spp., p. 474. In Abstracts of the 96th General Meeting of the American Society for Microbiology 1996. American Society for Microbiology, Washington, D.C.

30. Gaydos, C. A., L. Palmer, T. C. Quinn, S. Falkow, and J. J. Eiden. 1993. Phylogenetic relationship of Chlamydia pneumoniae to Chlamydia psittaci and Chlamydia trachomatis as determined by analysis of $16 \mathrm{~S}$ ribosomal DNA sequences. Int. J. Syst. Bacteriol. 43:610-612.

30a.Genetics Computer Group. 1994. Program manual for the Wisconsin package, version 8. Genetics Computer Group, Madison, Wis.

31. Girjes, A. A., F. N. Carrick, and M. F. Lavin. 1994. Remarkable sequence relatedness in the DNA encoding the major outer membrane protein of Chlamydia psittaci (koala type I) and Chlamydia pneumoniae. Gene 138:139142.

32. Girjes, A. A., A. Hugall, D. M. Graham, T. F. McCaul, and M. F. Lavin. 1993 Comparison of type I and type II Chlamydia psittaci strains infecting koalas (Phascolarctos cinereus). Vet. Microbiol. 37:65-83.

33. Girjes, A. A., A. Hugall, P. Timms, and M. F. Lavin. 1988. Two distinct forms of Chlamydia psittaci associated with disease and infertility in Phascolarctos cinereus (koala). Infect. Immun. 56:1897-1900.

34. Golub, O. J., and J. C. Wagner. 1947. Studies on the interference phenomenon with certain members of the psittacosis-lymphogranuloma group of viruses. J. Immunol. 59:59-70.

35. Grayston, J. T., C.-C. Kuo, L. A. Campbell, and S.-P. Wang. 1989. Chlamydia pneumoniae sp. nov. for Chlamydia sp. strain TWAR. Int. J. Syst. Bacteriol. 39:88-90.

36. Gutell, R. R. 1994. Lessons from an evolving rRNA: 16S and 23S rRNA structures from a comparative perspective. Microbiol. Rev. 58:10-26.

37. Hanna, L. 1962. Isolation of trachoma and inclusion conjunctivitis viruses in the U.S. Ann. N.Y. Acad. Sci. 98:24-30.

38. Herring, A. J. 1993. Typing Chlamydia psittaci-a review of methods and recent findings. Br. Vet. J. 149:455-475.

39. Herring, A. J. 1991. PCR test for Chlamydia psittaci. Vet. Rec. 128:555.

40. Herring, A. J., I. E. Anderson, M. McClenaghan, N. F. Inglis, H. Williams, B. A. Matheson, C. P. West, M. Rodger, and R. P. Brettle. 1987. Restriction endonuclease analysis of DNA from two isolates of Chlamydia psittaci obtained from human abortions. Br. Med. J. 295:1239.

41. Illner, V. F. 1960. Zur Frage der Übertragung des Ornithosevirus durch das Ei. Monatsh. Veterinaermed. 17:116-117.

42. Jukes, T. H., and C. R. Cantor. 1969. Evolution of protein molecules, p. 21-132. In H. N. Munro (ed.), Mammalian protein metabolism, vol. III Academic Press, New York, N.Y.

43. Kahane, S., E. Metzer, and M. G. Friedman. 1995. Evidence that the novel microorganism 'Z' may belong to a new genus in the family Chlamydiaceae. FEMS Microbiol. Lett. 126:203-208.

44. Kaltenboeck, B., K. G. Kousoulas, and J. Storz. 1993. Structures of and allelic diversity and relationships among the major outer membrane protein (ompA) genes of the four chlamydial species. J. Bacteriol. 175:487-502.

45. Kölbl, O., H. Burtscher, and J. Hebenstreit. 1970. Polyarthritis bei Schlachtschweinen. Wien. Tieraerztl. Monatsschr. 57:355-361.

46. Kuo, C.-C., L. A. Jackson, L. A. Campbell, and J. T. Grayston. 1995. Chlamydia pneumoniae (TWAR). Clin. Microbiol. Rev. 8:451-461.

47. McClenaghan, M., A. J. Herring, and I. D. Aitken. 1984. Comparison of Chlamydia psittaci isolates by DNA restriction endonuclease analysis. Infect. Immun. 45:384-389.

48. McClenaghan, M., N. F. Inglis, and A. J. Herring. 1991. Comparison of isolates of Chlamydia psittaci of ovine, avian and feline origin by analysis of polypeptide profiles from purified elementary bodies. Vet. Microbiol. 26: 269-278.

49. McNutt, S. H., and E. F. Waller. 1940. Sporadic bovine encephalomyelitis (Buss disease). Cornell Vet. 30:437-448.

50. Moulder, J. W., T. P. Hatch, C.-C. Kuo, J. Schachter, and J. Storz. 1984. Genus Chlamydia, p. 729-739. In N. R. Krieg and J. G. Holt (ed.), Bergey's manual of systematic bacteriology, vol. 1. The Williams \& Wilkins Co. Baltimore, Md

51. Murray, E. S. 1964. Guinea pig inclusion conjunctivitis virus. I. Isolation and identification as a member of the psittacosis-lymphogranuloma-trachoma group. J. Infect. Dis. 114:1-12.

52. Nigg, C. 1942 . Unidentified virus which produces pneumonia and systemic infection in mice. Science 95:49-50. 
53. Page, L. A. 1958. Measurement of pathogenicity of turkey ornithosis agents for mice. Avian Dis. 3:23-27.

54. Page, L. A. 1959. Experimental ornithosis in turkeys. Avian Dis. 3:51-66.

5. Page, L. A. 1967. Comparison of "pathotypes" among chlamydial (psittacosis) strains recovered from diseased birds and mammals. Bull. Wildl. Dis. Assoc. 2:166-175.

56. Page, L. A. 1968. Proposal for the recognition of two species in the genus Chlamydia Jones, Rake, and Stearns, 1945. Int. J. Syst. Bacteriol. 18:51-66.

57. Page, L. A., and R. A. Bankowski. 1960. Factors affecting the production and detection of ornithosis antibodies in infected turkeys. Am. J. Vet. Res. 21 971-978.

58. Page, L. A., and R. C. Cutlip. 1968. Chlamydial polyarthritis in Iowa lambs Iowa Vet. 39:10-18.

59. Papp, J. R., P. E. Shewen, and C. J. Gartley. 1994. Abortion and subsequent excretion of chlamydiae from the reproductive tract of sheep during estrus. Infect. Immun. 62:3786-3792.

60. Perez-Martinez, J. A., and J. Storz. 1985. Antigenic diversity of Chlamydia psittaci of mammalian origin determined by microimmunofluorescence. Infect. Immun. 50:905-910.

61. Peterson, E. M., and L. M. de la Maza. 1988. Restriction endonuclease analysis of DNA from Chlamydia trachomatis biovars. J. Clin. Microbiol. 26: 625-629.

62. Pettersson, B., and C. M. Black. GenBank accession numbers U73782 and U73785.

62a.Pudjiatmoko, H. Fukushi, Y. Ochiai, T. Yamaguchi, and K. Hirai. 1997 Phylogenetic analysis of the genus Chlamydia based on 16S rRNA gene sequences. Int. J. Syst. Bacteriol. 47:425-431.

63. Rodolakis, A., F. Bernard, and F. Lantier. 1989. Mouse models for evaluation of virulence of Chlamydia psittaci isolated from ruminants. Res. Vet. Sci. 46:34-39.

64. Rodolakis, A., and A. Souriau. 1992. Restriction endonuclease analysis of DNA from ruminant Chlamydia psittaci and its relation to mouse virulence. Vet. Microbiol. 31:263-271.

65. Rodolakis, A. Personal communication.

66. Rogers, D. G., and A. A. Andersen. 1996. Intestinal lesions caused by two swine chlamydial isolates in gnotobiotic pigs. J. Vet. Diagn. Invest. 8:433440

67. Rogers, D. G., A. A. Andersen, and B. D. Hunsaker. 1996. Lung and nasal lesions caused by a swine chlamydial isolate in gnotobiotic pigs. J. Vet. Diagn. Invest. 8:45-55.

68. Sambrook, J., E. F. Fritsch, and T. Maniatis. 1989. Molecular cloning: a laboratory manual, 2nd ed. Cold Spring Harbor Press, Cold Spring Harbor. N.Y

69. Sayada, C. 1994. Homogeneity of the major outer membrane protein gene of feline Chlamydia psittaci. Res. Vet. Sci. 56:116-118.

70. Schachter, J., and K. F. Meyer. 1969. Lymphogranuloma venereum. II Characterization of some recently isolated strains. J. Bacteriol. 99:636-638.

71. Schliefer, K. H., and E. Stackebrandt. 1983. Molecular systematics of prokaryotes. Annu. Rev. Microbiol. 37:143-187.

72. Scieux, C., F. Grimont, B. Regnault, and P. A. D. Grimont. 1992. DNA fingerprinting of Chlamydia trachomatis by use of ribosomal RNA, oligonucleotide and randomly cloned DNA probes. Res. Microbiol. 143:755-765.

73. Spalatin, J., C. E. O. Fraser, R. Connell, R. P. Hanson, and D. T. Berman. 1966. Agents of psittacosis-lymphogranuloma venereum group isolated from muskrats and snowshoe hares in Saskatchewan. Can. J. Comp. Med. Vet. Sci. 30:260-264

74. Srivastava, A. K., and D. Schlessinger. 1990. rRNA processing in Escherichia coli, p. 426-434. In W. E. Hill, P. B. Moore, A. Dahlberg, D. Schlessinger, R. A. Garrett, and J. R. Warner (ed.), The Ribosome. Structure, function, and evolution. American Society for Microbiology, Washington, D.C.

75. Stackebrandt, E. Personal communication.

76. Stackebrandt, E., and B. M. Goebel. 1994. Taxonomic note: a place for DNA-DNA reassociation and 16S rRNA sequence analysis in the present species definition in bacteriology. Int. J. Syst. Bacteriol 44:846-849.

77. Stamp, J. T., A. D. McEwen, J. A. A. Watt, and D. I. Nisbet. 1950. Enzootic abortion in ewes. Vet. Rec. 62:251-254

78. Stills, H. F., Jr., J. G. Fox, B. J. Paster, and F. E. Dewhirst. 1991. A "new" Chlamydia sp. strain SFPD isolated from transmissible proliferative ileitis in hamsters. Microbiol. Ecol. Health Dis. 4:S99.

79. Storey, C., M. Lusher, and S. J. Richmond. 1992. Use of comparative MOMP gene sequence data for subdivision of Chlamydia psittaci $i$ species, $\mathrm{p}$. 191. In P.-A. Mårdh, M. LaPlaca, and M. Ward (ed.), Proceedings of the European Society for Chlamydia Research. Uppsala University Centre for STD Research, Uppsala, Sweden.

80. Storey, C., M. Lusher, P. Yates, and S. Richmond. 1993. Evidence for Chlamydia pneumoniae of non-human origin. J. Gen. Microbiol. 139:26212626.

81. Storz, J. 1966. Psittacosis-lymphogranuloma infection of sheep. Antigenic structures and interrelations of PL agents associated with polyarthritis, en zootic abortion, intrauterine and latent intestinal infections. J. Comp. Pathol. 76:351-362.

82. Storz, J., D. G. McKercher, J. A. Howarth, and O. C. Straub. 1960. The isolation of a viral agent from epizootic bovine abortion. J. Am. Vet. Med. Assoc. 137:509-514.

83. Swofford, D. L. 1993. PAUP: phylogenetic analysis using parsimony, version 3.1. Illinois Natural History Survey, Champaign.

84. Timms, P., F. W. Eaves, A. A. Girjes, and M. F. Lavin. 1988. Comparison of Chlamydia psittaci isolates by restriction endonuclease and DNA probe analysis. Infect. Immun. 56:287-290.

85. Vandamme, P., B. Pot, M. Gillis, P. De Vos, K. Kersters, and J. Swings. 1996 Polyphasic taxonomy, a consensus approach to bacterial systematics. Microbiol. Rev. 60:407-438

86. Van de Peer, Y., J.-M. Neefs, P. De Rijk, P. De Vos, and R. De Wachter. 1994 About the order of divergence of the major bacterial taxa during evolution. Syst. Appl. Microbiol. 17:32-38.

87. Wang, S.-P., and J. T. Grayston. 1962. Classification of trachoma virus strains by protection of mice from toxic death. J. Immunol. 90:849-856.

88. Wang, S.-P., C.-C. Kuo, R. C. Barnes, R. S. Stephens, and J. T. Grayston. 1985. Immunotyping of Chlamydia trachomatis with monoclonal antibodies. J. Infect. Dis. 152:791-800.

89. Ward-Rainey, N., F. A. Rainey, E. M. H. Wellington, and E. Stackebrandt. 1996. Physical map of the genome of Planctomyces limnophilus, a representative of the phylogenetically distinct planctomycete lineage. J. Bacteriol. 178:1908-1913.

90. Weisburg, W. G., T. P. Hatch, and C. R. Woese. 1986. Eubacterial origin of chlamydiae. J. Bacteriol. 167:570-574.

91. Weisburg, W. G. Personal communication.

92. Weisburg, W. G. GenBank accession number X07408.

93. Werdin, R. E. 1972. Studies on the pathogenesis of chlamydial pneumonia in calves. Ph.D. dissertation. University of Minnesota, Minneapolis.

94. Wills, J. M. G. Watson, M. Lusher, D. Wood, and S. J. Richmond. 1990 Characterisation of Chlamydia psittaci isolated from a horse. Vet. Microbiol. 24:11-19.

95. Woese, C. R. 1982. Archaebacteria and cellular origins: an overview. Zentralbl. Bakteriol. Parasitenkd. Infektionskr. Hyg. Abt. 1 Orig. Reihe C 3:1 17.

96. Woese, C. R. 1994 . There must be a prokaryote somewhere: microbiology's search for itself. Microbiol. Rev. 58:1-9.

97. Zhang, Y.-X., J. G. Fox, Y. Ho, L. Zhang, H. F. Stills, Jr., and T. F. Smith 1993. Comparison of the major outer-membrane protein (MOMP) gene of mouse pneumonitis (MoPn) and hamster SFPD strains of Chlamydia trachomatis with other Chlamydia strains. Mol. Biol. Evol. 10:1327-1342.

98. Zhang, Y.-X., S. G. Morrison, H. D. Caldwell, and W. B. Baehr. 1989 Cloning and sequence analysis of the major outer membrane protein genes of two Chlamydia psittaci strains. Infect. Immun. 57:1621-1625.

99. Zhang, Y.-X. GenBank accession number M83313. 